\title{
KEDUDUKAN KREDITUR ATAS OBJEK JAMINAN FIDUSIA YANG \\ BELUM DIBAGI KARENA ADANYA PERCERAIAN
}

\author{
Oleh : \\ Fandi Septi Riyanto \\ Email :fandisepti@yahoo.com
}

\begin{abstract}
Fiduciary is the transfer of ownership rights of an object on the basis of trust provided that the object whose ownership rights are transferred remains in the possession of the owner of the object. Whereas what is meant by Fiduciary Guarantee is the guarantee right for movable objects both tangible and intangible and immovable objects, especially buildings that cannot be burdened with mortgages, which remain in the control of the Fiduciary Giver, as certain debt repayment collateral that gives priority position to Fiduciary Recipients against other creditors. Items loaded with a Fiduciary Guarantee must be registered. Registration for a Fiduciary Guarantee is carried out at the Fiduciary Registration Office. However, if the registration of Fiduciary Guarantee to be registered with the Office of Fiduciary Registration is a matter of property that has not been shared with the former creditor's wife against the vehicle due to divorce, it can be said that the agreement can be canceled, so there is no legal certainty for the recipient of Fiduciary Guarantee. If the Fiduciary Registration Office issues and submits a Fiduciary Guarantee Certificate to the Fiduciary Recipient on the date that is the same as the date of receipt of the application for registration. This Fiduciary Guarantee Certificate is a copy of the Fiduciary Register Book. By obtaining a Fiduciary Guarantee certificate, the creditor or fiduciary guarantee recipient immediately has the right of direct execution (parate execution). The legal strength of the certificate is the same as the court's decision which has permanent legal force
\end{abstract}

Keywords : Fiduciary Guarantee, Creditors, Execution. 


\section{PENDAHULUAN}

\subsection{Latar Belakang Masalah}

Manusia merupakan makluk yang ingin mencukupi segala kebutuhannya. Baik dalam kebutuhan yang bersifat primer, sekunder atau tersier. Dalam mencukupi kebutuhan tersebut manusia dapat menjaminkan sebuah harta yang dimilikinya. Proses jaminan untuk mendapatkan fasilitas kredit dapat dinamakan dengan Hukum Jaminan. Hukum Jaminan merupakan keseluruhan dari kaidah-kaidah hukum yang mengatur hubungan hukum antara pemberi dan penerima jaminan dalam kaitannya dengan pembebanan jaminan untuk mendapatkan suatu fasilitas kredit.

Fasilitas kredit dalam hal ini adalah Fidusia yang merupakan pengalihan hak kepemilikan suatu benda atas dasar kepercayaan dengan ketentuan bahwa benda yang hak kepemilikannya dialihkan tersebut tetap dalam penguasaan pemilik benda. Untuk mendapatkan jaminan fidusia, benda yang bergerak yang menjadi objek jaminan harus didaftarkan ke kantor jaminan fidusia untuk mendapatkan sertifikat jaminan fidusia.

Sertifikat jaminan fidusia akan timbul apabila dilakukannya pendaftaran Jaminan Fidusia. Jika salah satu objek yang akan didaftarkan kepada Kantor Pendaftaran Fidusia terdapat permasalahan harta gono-gini yang belum dibaginya kepada mantan istri kreditur yang disebabkan putus karena perceraian terhadap kendaraan tersebut, maka dapat dikatakan perjanjian tersebut dapat dibatalkan, sehingga tidak ada kepastian hukum bagi penerima Jaminan Fidusia.

Berdasarkan pada uraian di atas, tulisan ini hendak membahas mengenai kedudukan kreditur terhadap objek jaminan fidusia yang belum terbagi karena perceraian.

\subsection{Perumusan Masalah}

Berdasarkan latar belakang yang telah dipaparkan di atas, maka permasalahan yang akan diteliti dapat dirumuskan sebagai berikut :

1. Apa akibat hukum pengalihan piutang perjanjian jaminan fidusia yang dibuat tanpa persetujuan istri yang telah bercerai ?

2. Bagaimana kedudukan kreditur terhadap jaminan fidusia yang telah didaftarkan ke lembaga jaminan dan penyelesaian sengketa jika debitur wanprestasi ? 


\section{METODE PENELITIAN}

Tulisan ini menggunakan metode penelitian hukum normatif, yaitu meneliti hukum dari perspektif internal dengan objek penelitiannya adalah norma hukum. Dengan kata lain penelitian hukum yang meletakkan hukum sebagai sebuah bangunan sistem norma. Sistem norma yang dimaksud adalah mengenai asasasas, norma, kaidah dari peraturan perundangan, putusan pengadilan, perjanjian serta doktrin (ajaran). ${ }^{1}$

Pendekatan yang digunakan adalah pendekatan perundang-undangan dan pendekatan konseptual. Pendekatan perundang-undangan atau statute approach digunakan jika permasalahan penelitiannya mempermasalahkan konflik norma yang terjadi secara vertikal maupun horizontal. Misalnya norma yang berada pada sebuah peraturan perundang-undangan yang bersifat khusus atau umum, ataukah berada pada yang lebih tinggi atau lebih rendah, dan berada pada yang lama atau yang baru.

Pendekatan konseptual atau conceptual approach beranjak dari pandangan-pandangan dan doktrin-doktrin yang berkembang di dalam ilmu hukum, sehingga dapat menemukan ide-ide yang melahirkan pengertian-pengertian hukum,

${ }^{1}$ Imade Pasek Diantha, 2016, Metodologi Penelitian Hukum Normatif dalam Justifikasi Teori Hukum (Jakarta:Prenada MediaGrup). hlm 12 konsep-konsep hukum, dan asas-asas hukum yang relevan dengan isu yang dihadapi. $^{2}$

\section{HASIL DAN PEMBAHASAN}

3.1. Akibat Hukum Pengalihan Piutang Perjanjian Jaminan Fidusia Yang Dibuat Tanpa Persetujuan Istri Yang Telah Bercerai

Istilah jaminan merupakan terjemahan dari Bahasa Belanda, yaitu zekerheid atau cautie. Zekerheid atau cautie mencakup secara umum cara-cara kreditur menjamin dipenuhinya tagihan, disamping pertanggung jawaban umum debitur terhadap barangnya. Sedangkan menurut Hartono Hadisoeprapto hukum jaminan merupakan "Sesuatu yang diberikan kepada kreditur untuk menimbulkan keyakinan bahwa debitur akan memenuhi kewajiban yang dapat dinilai dengan uang yang timbul dari suatu perikatan". 3

Jaminan merupakan mempunyai kedudukan dan manfaat yang menunjang dalam pembangunan perekonomian masyarakat. Oleh karena itu lembaga jaminan dapat memberikan manfaat bagi debitur dan kreditur, antara lain : terwujudnya keamanan terhadap transaksi

Ibid, hlm. 159

H. Salim HS,2004, "Perkembangan Hukum Jaminan di Indonesia", Jakarta, PT. Raja Grafindo Persada, hlm. 22 
dagang yang ditutup dan memberikan kepastian hukum bagi kreditur. ${ }^{4}$

Jaminan kebendaan mempunyai ciriciri "kebendaan" dalam arti memberikan hak mendahului di atas benda-benda tertentu dan mempunyai sifat melekat dan mengikuti benda yang bersangkutan. Pada dasarnya perjanjian kebendaan dapat dibedakan menjadi 2 macam, yaitu perjanjian pokok dan perjanjian assecoir. Perjanjian pokok merupakan perjanjian untuk mendapatkan fasilitas kredit dari lembaga perbankan atau lembaga keuangan non bank.

Jaminan kredit menurut KUH Perdata dibagi dua, yaitu : (a) Jaminan Umum, dan (b) Jaminan Khusus. Jaminan Umum diatur dalam Pasal 1313 KUH Perdata yang menyatakan "Segala kebendaan si berhutang, baik yang bergerak maupun tidak bergerak, baik yang sudah ada maupun yang baru akan ada di kemudian hari menjadi tanggungan untuk segala perikatan perseorangan". Sedangkan suatu Jaminan Khusus diberikan oleh undang-undang untuk melindungi kepentingan kreditor. Jaminan Khusus dinilai lebih memberikan perlindungan bagi kreditor karena objek jaminannya jelas dan barang yang dijaminkan diikat dalam suatu Perjanjian Jaminan.

4 Ibid, hlm. 28
Sebelum berlakunya UndangUndang Nomor 42 Tahun 1999 tentang Fidusia, maka yang menjadi objek jaminan fidusia merupakan benda bergerak yang terdiri dari benda persediaan (inventory), benda dagang, piutang dan kendaraan bermotor. Akan tetapi dengan berlakunya Undang-Undang Nomor 42 Tahun 1999 tentang Fidusia, maka objek jaminan fidusia diberikan pengertian luas, antara lain :

1. Benda bergerak, baik yang berwujud maupun tidak berwujud.

2. Benda tidak bergerak, khususnya bagunan yang tidak dibebani dengan hak tanggungan.

Subjek dari Jaminan Fidusia merupakan pemberi dan penerima fidusia. Pemberi Fidusia merupakan orang perorangan atau koporasi pemilik benda yang menjadi objek jaminan fidusia, Penerima Fidusia merupakan orang perorangan atau korporasi yang mempunyai piutang yang pembayarannya dijamin dengan pembayaran jaminan fidusia. Sifat jaminan fidusia adalah perjanjian ikutan (accesoir) dari suatu perjanjian pokok yang menimbulkan kewajiban bagi para pihak untuk memenuhi suatu prestasi. Jaminan fidusia biasanya dituangkan dalam akta notaris. Substansi akta perjanjian fidusia ini telah dibakukan oleh pemerintah, dengan maksud dan tujuan guna untuk 
melindungi pemberi fidusia terutama dalam masyarakat dengan ekonomi lemah.

Menurut Subekti, S.H, Perjanjian merupakan suatu peristiwa dimana orang berjanji kepada seseorang lain atau dimana dua orang itu saling berjanji untuk melaksanakan sesuatu hal. Dalam peristiwa ini timbullah suatu hubungan hukum antara dua orang yang bisa dinamakan Perikatan. Perjanjian tersebut menerbitkan suatu perikatan antara dua orang yang membuatnya, dan perikatan itu berupa suatu rangkaian perkataan yang mengandung unsur janji-janji atau kesanggupan yang diucapkan atau ditulis. ${ }^{5}$

Menurut Pasal 1313 KUH Perdata, Perjanjian dapat dirumuskan, yaitu : suatu perbuatan dengan mana satu orang atau lebih mengikatkan dirinya terhadap satu orang atau lebih lainnya. Sebagaimana suatu perjanjian dapat dijelaskan sebagai berikut :

\section{Prestasi}

Pengertian suatu Prestasi dalam hukum kontrak dimaksudkan sebagai suatu pelaksanaan hal-hal yang tertulis dalam suatu kontrak oleh pihak yang telah mengikatkan diri untuk itu. Suatu pelaksaan mana dengan kontrak yang bersangkutan. ${ }^{6}$

\footnotetext{
${ }^{5}$ H.R. Daeng Naja, 2005, "Hukum Kredit dan Bank Garansi”, Cetakan ke -1, Penerbit PT. Citra Aditya Bakti, Bandung, hlm. 175.

${ }^{6}$ Subekti, 2008. Pokok-Pokok Hukum Perdata, PT. Intermasa, Jakarta, hlm.120
}

Menurut Pasal 1234 KUH Perdata bentuk dari suatu prestasi berupa :

(1). Memberikan sesuatu

(2). Berbuat sesuatu

(3). Tidak berbuat sesuatu

2. Wanprestasi

Suatu perjanjian dapat terlaksana dengan baik, apabila salah satu pihak telah memenuhi suatu perjanjian masing-masing seperti yang diperjanjikan tanpa adanya salah satu pihak yang dirugikan. Namun ada kalanya perjanjian tersebut tidak terlaksana dengan baik karena terjadinya wanprestasi yang dilakukan oleh salah satu pihak. Arti wanprestasi berasal dari bahasa Belanda, yang artinya prestasi buruk. Adapun yang dimaksud dengan wanprestasi adalah suatu keadaan dikarenakan kelalaian atau kesalahannya, sehingga debitur tidak dapat memenuhi prestasi seperti yang telah ditentukan dalam perjanjian dan bukan dalam keadaan yang memaksa. $^{7}$

3. Ganti Rugi

Menurut Pasal 1244, Pasal 1245 dan Pasal 1246 KUH Perdata suatu ganti terdiri dari biaya, rugi dan bunga. Apabila undangundang menyebutkan rugi maka yang dimaksud adalah suatu kerugian nyata dan dapat diduga atau diperkirakan pada saat perikatan itu diadakan, yang timbul

\footnotetext{
${ }^{7}$ Nindyo Pramono, 2003, Hukum Komersil, Pusat Penerbitan UT, Jakarta, hlm. 21
} 
sebagai akibat dari "ingkar janji”. ${ }^{8}$ Pada dasarnya suatu ganti rugi tersebut lazim dipergunakan ialah uang, namun selain uang masih ada bentuk-bentuk lain yang dipergunakan sebagai bentuk ganti rugi yaitu: pemulihan keadaan semua (in natura) dan larangan untuk mengulangi.

Sedangkan syarat sah perjanjian menurut Pasal 1320 KUH Perdata, yaitu : (1). Sepakat mereka yang mengikat dirinya, (2). Kecakapan untuk membuat suatu perjanjian , (3). Suatu hal tertentu, (4). Suatu sebab yang halal. Jika syarat objektif tidak terpenuhi, maka perjanjian secara otomatis dapat dinyatakan "batal demi hukum", artinya perjanjian itu dianggap tidak pernah ada sehingga tidak ada dasar untuk saling menuntut di pengadilan. Namun sebaliknya, jika syarat subyektif tidak terpenuhi, maka perjanjian itu tidak otomatis batal demi hukum, namun "dapat dibatalkan" jika salah satu pihak meminta pembatalan kepada pengadilan. $^{9}$

Perjanjian Jaminan sesuai PBI 9/2007 dapat berupa pengikatan agunan berdasarkan: (a) Hak Tanggungan, (b) Gadai, (c) Fidusia, (d) Hipotek, (e) Hak Jaminan atas Resi Gudang. ${ }^{10}$ Proses

\footnotetext{
8 Mariam Darus Badrulzaman, 2001, Asas-Asas Hukum Perjanjian, PT. Citra Aditya Bakti, Bandung, hlm. 21

${ }^{9}$ Iswi Hariyani, R.Serfianto, 2010 (a), Bebas Jeratan Utang Piutang,cetakan pertama.Yogyakarta: Pustaka Yustisia.hlm.60.

10 Ibid, hlm. 110
}

terjadinya Jaminan fidusia menurut Undang-Undang Nomor 42 tahun 1999, Jaminan Fidusia terjadi melalui 2 tahapan: 1) Tahapan Pembebanan Jaminan Fidusia Jaminan fidusia merupakan perjanjian ikutan dari suatu perjanjian pokok yang menimbulkan kewajiban bagi para pihak untuk memenuhi suatu prestasi. Pembebanan benda dengan jaminan fidusia dibuat dengan akta notaris dalam bahasa Indonesia dan merupakan akta jaminan fidusia. Terhadap pembuatan akta jaminan fidusia dikenakan biaya. Akta jaminan fidusia kurangnya memuat :

a. Identitas pihak Pemberi dan Penerima fidusia

b. Data perjanjian pokok yang dijamin fidusia

c. Uraian mengenai Benda yang menjadi obyek Jaminan Fidusia

d. Nilai penjaminan.

e. Nilai Benda yang menjadi obyek Jaminan Fidusia.

2) Tahapan Pendaftaran Jaminan Fidusia

Benda yang dibebani dengan jaminan fidusia wajib didaftarkan. Walaupun benda yang dijaminkan fidusia berada di luar wilayah republic Indonesia. Pendaftaran jaminan fidusia dilakukan pada Kantor pendaftaran fidusia. Permohonan pendaftaran jaminan fidusia dilakukan oleh penerima fidusia, kuasa atau wakilnya, dengan melampirkan 
pernyataan pendaftaran jaminan fidusia. Pernyataan pendaftaran memuat :

a. Identitas pihak Pemberi dan Penerima Fidusia

b. Tanggal,nomor akta jaminan Fidusia, nama, tempat kedudukan notaris yang membuat akta Jaminan Fidusia

c. Data perjanjian pokok yang dijamin fidusia

d. Uraian mengenai Benda yang menjadi obyek Jaminan Fidusia

e. Nilai penjaminan

f. Nilai benda yang menjadi objek jaminan fidusia.

Jaminan fidusia merupakan salah satu pranata lembaga jaminan yang berada di Indonesia. Jaminan fidusia diperuntukan bagi benda bergerak seperti sepeda motor maupun mobil. Untuk mendapatkan jaminan fidusia, benda bergerak itu harus didaftarkan untuk diberikan surat atau akta jaminan fidusia. Permohonan pendaftaran jaminan fidusia diajukan oleh penerima fidusia, kuasa atau wakilnya kepada Menteri.Undang-Undang Nomor 42 Tahun 1999 tentang Jaminan Fidusia menegaskan bahwa benda yang dibebani dengan jaminan fidusia wajib didaftarkan. Pendaftaran jaminan fidusia tersebut untuk memberikan kepastian hukum kepada para pihak yang berkepentingan.

Ketentuan yang terdapat dalam Pasal 2 Peraturan Menteri Keuangan Nomor 130
/PMK.010/2012 tentang Pendaftaran Jaminan Fidusia bagi perusahaan pembiayaan menyatakan "Perusahaan pembiayaan wajib mendaftarkan jaminan fidusia pada kantor pendaftaran fidusia paling lama 30 (tiga puluh) hari kalender terhitung sejak tanggal perjanjian pembiayaan yang disepakati dengan konsumen. ${ }^{11}$ Pada hakikatnya harta benda perkawinan antara suami istri meliputi harta yang dibawa kedalam perkawinan oleh suami istri atau yang bisa disebut sebagai harta bawaan, dan harta yang diperoleh selama perkawinan disebut juga sebagai harta bersama. Dalam Undang-Undang Perkawinan No 1 Tahun 1974, menganut suatu asas perpisahan harta yang sebagaimana diatur di dalam Pasal 35 Undang-Undang Perkawinan yang menggolongkan harta dalam perkawinan terbagi atas harta bersama dan harta bawaan. Harta bersama diatur dalam Pasal 35 ayat (1) Undang-Undang Perkawinan, yaitu :

a. Harta yang diperoleh sepanjang perkawinan berlangsung;

b. Harta yang diperoleh sebagai hadiah atau pemberian atau warisan apabila ditentukan demikian;

c. Hutang-hutang yang timbul selama perkawinan berlangsung kecuali yang

\footnotetext{
${ }^{11}$ Peraturan Menteri Keuangan Nomor 130 / PMK.010/2012 tentang Pendaftaran Jaminan Fidusia
} 
merupakan harta pribadi masingmasing suami istri.

Mengenai harta bersama, antara suami atau istri dapat bertindak atas persetujuan kedua belah pihak termasuk dalam hal utang terhadap lembaga pembiayaan. Apabila suatu debitur mengajukan permohonan utang disertai dengan jaminan kendaraan bermotor dan tanpa adanya persetujuan dengan istri maka tidak dapat dilakukan. Termasuk sisa hutang yang dibebankan oleh suami terhadap mantan istri yang telah bercerai yang sangat merugikan mantan istri tersebut, tanpa sepengatuhan istri suami mengajukan kredit pembiayaan dengan atas nama istri selaku penjamin. Hal ini tentu suami telah melakukan perbuatan melanggar hukum. Maka eksekusi yang dilakukan oleh kreditur apabila debitur sudah tidak mampu membayar utang yang telah jatuh tempo (wanprestasi) tidak dapat dilakukan.

Hak dan kewajiban yang setara diantara suami dan istri menimbulkan adanya tanggungjawab yang sama terhadap segala perbuatan hukum yang dilakukan oleh kedua belah pihak antara suami dan istri. Perbuatan hukum tersebut dapat dilakukan oleh salah satu pihak dengan adanya persetujuan pihak lainnya maupun secara bersama-sama antara suami dan istri. Tidak saling menjatuhkan dengan tujuan mendapatkan keuntungan semata sehingga salah satu pihak antara suami atau istri yang menjadi korban atas perbuatan hukum tersebut.

Menurut Pasal 36 ayat (1) UndangUndang Perkawinan, harta bersama pada umumnya akan dibagi dua secara proposional kepada masing-masing pihak apabila terjadi perceraian. Sedangkan apabila perkawinan putus disebabkan oleh kematian maka salah satu pihak maka harta bersama tetap pada keadaan semula dikuasai oleh pihak yang masih hidup. ${ }^{12}$ Menurut Pendapat Arista, dalam prakteknya perjanjian kredit yang tidak disetujui oleh salah satu pasangan baik itu suami ataupun istri tidak dimungkinkan, karena keduanya haruslah melakukan sebuah persetujuan, baik dalam bentuk tandatangan pernyataan dan harus hadir dalam pengajuan akad kredit. Kredit yang diajukan tidak disetujui oleh bank. Namun apabila suatu kredit yang hanya melibatkan personal seperti kredit tanpa agunan, cukup dihadiri oleh pihak bank yang bersangkutan tanpa perlu kehadiran atau persetujuan pasangannya. Namun apabila nantinya terjadi suatu sengketa, tidak bisa membayar suatu kredit maka pihak bank akan menagih debitur secara personal saja. $^{13}$

\footnotetext{
${ }^{12}$ Drajen Saragih, Pengantar Hukum Adat Indonesia, Tarsito, Bandung : 1948, hlm. 45

${ }^{13}$ Wawancara dengan Arista Puspamega, Staf Regional Bussiness Manager Bank Mandiri pada tanggal 4 Juli 2018.
} 
Suami dan istri sebagai debitur dalam perjanjian kredit dengan obyek jaminan fidusia dan jaminan tersebut merupakan jaminan harta bersama. Suami dan istri tersebut ternyata melakukan wanprestasi karena tidak dapat memenuhi kewajiban kepada kreditur. Haruslah bertanggungjawab atas segala perbuatan hukum yang telah dijalaninya. Apabila terjadi ingkar janji, maka suami dan istri sebagai debitur yang telah menandatangani akad perjanjian kredit harus merelakan harta bersamanya yang dijadikan sebagai jaminan dalam perjanjian kredit untuk dieksekusi, dan untuk selanjutnya dapat dilakukan lelang guna melunasi hutang.

\subsection{Kedudukan Kreditur Terhadap}

Jaminan Fidusia Yang Telah

Didaftarkan Ke Lembaga Jaminan

Fidusia Dan Penyelesaian Sengketa Jika Debitur Wanprestasi

Sesuai dengan Undang-Undang Nomor 42 Tahun 1999 tentang Jaminan Fidusia yang terdapat dalam Pasal 5 ayat (1) bahwa Pembebanan Benda dengan Jaminan Fidusia harus dibuat dengan akta notaris yang bersifat notariil yang merupakan Akta Jaminan Fidusia. Setelah pembuatan akta notariil atau dengan tahapan pembebanan dilaksakanakan berdasarkan ketenntuan Undang-Undang Nomor 42 Tahun 1999, akta jaminan fidusia tersebut yang telah dibuat wajib didaftarkan berdasarkan ketentuan Pasal 11 ayat (1) Undang-Undang Nomor 42 Tahun 1999, yang menyatakan bahwa "benda yang dibebani jaminan fidusia wajib didaftarkan".

Pendaftaran ini dilakukan guna memberikan perlindungan dan kepastian hukum bagi penerima ataupun pemberi jaminan fidusia. Apabila pembebanan jaminan fidusia yang tidak dibuatkan dengan akta notariil melalui notaris dan tidak didaftarkan maka jaminan tersebut tidak mempunyai sesuatu kekuatan hukum sehingga para pihak baik penerima ataupun pemberi jaminan fidusia mersakan dirugikan. Seperti adanya jaminan fidusia yang tanpa adanya suatu sepengetahuan kreditur atau adanya pengalihan barang fidusia oleh debitur. Selain itu pendaftaran fidusia memiliki asas publisitas, yakni terpublikasi jaminan hutang yang akan semakin baik sehingga kreditur atau masyarakat dapat mengetahui terhadap informasi-informasi sekitar jaminan hutang tersebut.

Asas publisitas ini merupakan sangat penting bagi masyarakat terhadap jaminanjaminan hutang yang fisik objek jaminannya diserahkan oleh kreditur, salah satu contohnya seperti jaminan fidusia ini. ${ }^{14}$ Sebagai suatu perjanjian accessoir, perjanjian jaminan fidusia memiliki ciri-

\footnotetext{
${ }^{14}$ Munir Fuady, Pengantar Hukum Bisnis, Citra Aditya, Bandung, 2005, hlm. 23.
} 
ciri sebagaimana diatur dalam UndangUndang No. 42 Tahun 1999 sebagaimana dijelaskan berikut :

1. Memberikan kedudukan yang mendahului kepada kreditur penerima fidusia terhadap kreditur lainnya sesuai dengan (Pasal 27 UUF). Penerima Fidusia memiliki hak yang didahulukan (privellege) terhadap kreditur lainnya. Hak yang didahulukan dihitung sejak tanggal pendaftaran benda yang menjadi obyek jaminan fidusia pada Kantor Pendaftaran Fidusia. hak yang didahulukan yang dimaksud adalah penerima fidusia dalam mengambil suatu pelunasan piutang atau hasil eksekusi benda yang telah menjadi objek jaminan fidusia;

2. Selalu mengikuti objek yang dijaminkan di tangan siapapun terhadap obyek itu berada pada droit de suite (Pasal 20 UUF ). Jaminan fidusia tetap mengikuti benda yang menjadi obyek jaminan fidusia dalam tangan siapapun juga benda itu berada.

3. Dalam memenuhi asas spesialitas dan publisitas sehingga dapat mengikat suatu pihak ketiga dan memberikan jaminan kepastian hukum kepada pihak-pihak yang berkepentingan terkait dengan jaminan fidusia ini sesuai dengan Pasal 6 dan Pasal 11 UUF. Untuk memenuhi suatu asas spesialitas dalam ketentuan Pasal 6
UUF, maka akta jaminan fidusia sekurang-kurangnya memuat :

a. Identitias pihak pemberi dan penerima jaminan fidusia

b. Data perjanjian pokok yang dijamin fidusia

c. Uraian mengenai benda yang menjadi obyek jaminan fidusia

d. Nilai penjamin dan;

e. Nilai benda suatu obyek yang menjadi jaminan fidusia

f. Mudah dan pasti dalam pelaksanaan eksekusi (Pasal 29 UUF).

Sebuah akta otentik yang sempurna menurut pendapat Irawan Soerodjo, dilihat dari bentuk luarnya sebagai suatu akta yang memenuhi syarat formal, maka ada 3 (tiga) unsur esensial yang membangun suatu akta, yaitu akta tersebut dibuat dengan adanya arahan dari undangundang, dibuat oleh dan dihadapan pejabat umum, dibuat oleh atau dihadapan Pejabat Umum yang berwenang dalam pembuatan serta pengerluaran akta tersebut. ${ }^{15}$

Suatu unsur dalam pembuatan suatu akta otentik yaitu, seperti informasi dalam akta adalah untuk pembuktian yang benar, nyata, sesuai dengan perundang-undangan, dibuat oleh pejabat umum atau pejabat berwenang dalam bidang hukum.

15 Soerodjo, Irawan. Kepastian Hukum Atas Jaminan Fidusia, Sinar Grafika, Surabaya, 2009. Hlm. 39 
Eksekusi jaminan fidusia didasarkan pada sertifikat jaminan fidusia, sertifikat jaminan fidusia ditertibkan dan diserahkan oleh Kantor Pendaftaran Fidusia kepada Penerima jaminan fidusia memuat tanggal yang sama dengan tanggal penerimaan pendaftaran jaminan fidusia, sertifikat jaminan fidusia merupakan salinan dari Buku Daftar Fidusia, dan memuat catatan tentang hal-hal yang dinyatakan dalam pendaftaran jaminan fidusia. ${ }^{16}$ Dalam hal suatu debitur atau pemberi jaminan fidusia telah melakukan cidera janji (wanprestasi), pemberi fidusia wajib menyerahkan objek jaminan fidusia dalam rangka melaksanakan eksekusi terkait dengan perjanjian fidusia yang telah disepakati diawal. Suatu eksekusi dapat dilaksanakan dengan cara pelaksanaan suatu titel eksekutorial oleh penerima fidusia yakni lembaga perbankan atau lembaga pembiayaan lainnya langsung dapat dilakukan oleh lembaga parate eksekusi terhadap penjualan benda obyek jaminan fidusia atas kekuasaannya sendiri.

Pelaksanaan parate eksekusi tersebut dilakukan dengan cara menjual obyek jaminan fidusia melalui pelelangan umum serta mengambil pelunasan dari hasil penjualan obyek jaminan fidusia yang telah di eksekusi. Penjualan obyek jaminan fidusia juga dapat dilakukan penjualan dibawah tangan, dengan persetujuan

\footnotetext{
16 Ibid, hlm. 139
}

adanya suatu kesepakatan antara pemberi dan penerima jaminan fidusia tersebut.

Apabila perjanjian fidusia yang dibuat tanpa menggunakan bentuk Akta Notariil dan tidak didaftarkan ke Kantor Pendaftaran fidusia mempunyai suatu akibat hukum yakni Perjanjian dengan jaminan fidusia tersebut hanyalah berupa Akta dibawah tangan yang tidak mempunyai suatu nilai eksekutorial untuk mengeksekusi obyek jaminan tersebut secara langsung. Proses suatu eksekusi dapat dilakukan, akan tetapi dengan cara melakukan gugatan keperdataan ke Pengadilan Negeri yang berwenang dan proses persidangan yang cukup lama sampai dengan putusan yang berkekuatan hukum tetap ( inkracht van gewijsde). Dan hal itu juga dapat menjadi pertimbangan bagi konsumen yang memang benar-benar melaksanakan tanggung jawabnya yakni melunasi sisa utangnya kepada lembaga pembiayaan namun ada juga konsumen yang tidak bisa melunasinya. ${ }^{17}$

Cara penerapan suatu eksekusi diatur dalam Pasal 32 Undang-Undang No, 42 Tahun 1999 tentang Jaminan Fidusia, yang dimana pelaksanaan eksekusi yang dilakukan Penerima Fidusia terhadap Pemberi Fidusia haruslah berpedoman pada peraturan undang-undang, dan apabila

\footnotetext{
${ }^{17}$ Widjaya, Gunawan dan Ahmad Yani. Jaminan Fidusia, Raja Grafindo Persada, Bandung : 2011. hlm. 47
} 
dilanggar maka eksekusi yang dilakukan merupakan batal demi hukum. ${ }^{18}$ Penyelesaian kredit macet, menurut Herowati Poesoko dapat ditempuh melalui 3 (tiga) cara antara lain : (a). parate executie. (b) title executorial, (c). penjualan di bawah tangan. ${ }^{19}$

Pengertian 'eksekusi” dapat dibagi menjadi dua, yaitu "eksekusi dalam arti sempit" dan "eksekusi dalam arti luas". Eksekusi dalam arti sempit adalah pelaksanaan putusan Pengadilan yang telah mempunyai kekuatan hukum tetap, sedangakan eksekusi dalam arti luas adalah pelaksanaan pemenuhan hak berdasarkan putusan pengadilan yang berkekuatan hukum tetap atau berdasarkan akta bertitel eksekutorial dengan atau tanpa fiat pengadilan atau secara parate executie atau penjualan dibawah tangan. ${ }^{20}$

Terkait dengan status kebendaan dan kepemilikan objek jaminan fidusia telah diatur dalam Pasal 33 Undang-Undang No. 42 Tahun 1999 tentang Jaminan Fidusia yang tidak memperbolehkan suatu kreditur untuk mengambil hak kepemilikan objek jaminan fidusia, meskipun debitur tersebut wanprestasi. Keputusan tersebut tidak lain merupakan mengambil jalan tengah untuk eksekusi sesuai suatu prosedur yang diatur

\footnotetext{
18 Soerodjo, Irawan, Op.Cit, hlm. 29

${ }^{19}$ Herowati Poesoko, 2007, "Parate Executie Obyek Hak Tanggungan" (Inkonsistensi, Konflik Norma dan Kesesatan Penalaran dalam UUHT), Penerbit LaksBang Pressindo, hlm.4

20 Ibid, hlm. 130.
}

dalam Pasal 29 Undang-Undang No. 42 Tahun 1999 tentang Jaminan Fidusia.

Apabila kreditur tetap pada pendiriannya dan melanggar suatu peraturan yang telah ditetapkan oleh UndangUndang maka perjanjian tersebut batal demi hukum. Namun apabila terjadi kelebihan nilai benda yang dijual untuk melunasi hutang debitur, maka penjualan objek jaminan kelebihan tersebut harus tetap diserahkan kepada debitur, yang mana tercantum pada Pasal 34 UndangUndang No. 42 Tahun 1999.

Advokat Grace P. Nugroho menjelasakan dalam artikel yang berjudul Eksekusi Terhadap Benda Objek Perjanjian Fidusia Dengan Akta di Bawah Tangan, saat ini banyak lembaga pembiayaan (finance) dan bank (bank umum maupun perkreditan) menyeleng-garakan pembiayaam bagi konsumen (consumer finance), sewa guna usaha (leasing), dan anjak piutang (factoring). ${ }^{21}$

Suatu akibat hukum bagi para pemegang jaminan fidusia apabila suatu jaminan fidusia belum di daftarkan maka kreditur tidak akan mendapatkan suatu sertifikat, sehingga tidak akan dianggap sah atau dapat dikatakan sebagai suatu akta di bawah tangan, suatu diamana yang menyetujui hanya para pihak saja dan tidak

\footnotetext{
21 Nugroho, Grace P., Konsepsi Hukum Dalam Perjanjian Jaminan Fidusia. Ghalia Indonesia, Bandung: 2003, hlm. 43
} 
dibuat dihadapan pihak yang berwenang yakni notaris.

Dalam praktik perbankan, jika debitur melakukan wanprestasi dan portofolio kreditnya menjadi bermasalah, maka pihak bank pertama kali akan melakukan upaya Penyelamatan Kredit melalui Penjadwalan Kembali (Rescheduling), Persyaratan Kembali (Reconditioning), dan Penataan Kembali (Restructuring). Jika upaya Penyelamatan Kredit Bermasalah tersebut tidak berhasil, maka pihak bank dapat melakukan program Hapus Buku dan Hapus Tagih tersebut tetap tidak berhasil, maka pihak Bank dapat melakukan eksekusi atau penyelesaian kredit macet melalui cara-cara non litigasi (di luar pengadilan) maupun litigasi (proses pengadilan). ${ }^{22}$

\section{KESIMPULAN}

1. Jaminan kredit menurut KUH Perdata dibagi dua, yaitu : (a) Jaminan Umum, dan (b) Jaminan Khusus. Jaminan Umum diatur dalam Pasal 1313 KUH Perdata yang menyatakan "Segala kebendaan si berhutang, baik yang bergerak maupun tidak bergerak, baik yang sudah ada maupun yang baru akan ada di kemudian hari menjadi tanggungan untuk segala perikatan

Iswi Hariyani, R.Serfianto, 2010, Op.Cit, hlm. 114 perseorangan". Sedangkan suatu Jaminan Khusus diberikan oleh undang-undang untuk melindungi kepentingan kreditor. Jaminan Khusus dinilai lebih memberikan perlindungan bagi kreditor karena objek jaminannya jelas dan barang yang dijaminkan diikat dalam suatu Perjanjian Jaminan. Suami dan istri sebagai debitur dalam perjanjian kredit dengan obyek jaminan fidusia dan jaminan tersebut merupakan jaminan harta bersama. Suami dan istri tersebut ternyata melakukan wanprestasi karena tidak dapat memenuhi kewajiban kepada kreditur. Haruslah bertanggungjawab atas segala perbuatan hukum yang telah dijalaninya.

2. Apabila suatu bentuk perjanjian fidusia yang dibuat tanpa menggunakan bentuk Akta Notariil dan tidak didaftarkan ke Kantor Pendaftaran fidusia mempunyai suatu akibat hukum yakni Perjanjian dengan jaminan fidusia tersebut hanyalah berupa Aka dibawah tangan yang tidak mempunyai suatu nilai eksekutorial untuk mengeksekusi obyek jaminan tersebut secara langsung. Proses suatu eksekusi dapat dilakukan, akan tetapi dengan cara melakukan gugatan keperdataan via Pengadilan Negeri yang berwenang dan menghadapi suatu proses persidangan yang cukup lama sampai 
dengan putusan yang berkekuatan DAFTAR PUSTAKA

hukum tetap (inkracht van gewijsde).

Hal itu juga dapat menjadi pertimbangan bagi konsumen yang

Drajen Saragih, Pengantar Hukum Adat Indonesia, Tarsito, Bandung : 1948.

memang benar-benar melaksanakan tanggung jawabnya yakni melunasi sisa utangnya kepada lembaga pembiayaan namun ada juga konsumen yang tidak bisa melunasinya.

Herowati Poesoko, 2007, "Parate Executie Obyek Hak Tanggungan” (Inkonsistensi, Konflik Norma dan Kesesatan Penalaran dalam UUHT), Penerbit LaksBang Pressindo

H. Salim HS, "Perkembangan Hukum Jaminan di Indonesia",2004, Jakarta, PT. Raja Grafindo Persada.

H.R. Daeng Naja, 2005, "Hukum Kredit dan Bank Garansi", Cetakan ke -1, Penerbit PT. Citra Aditya Bakti, Bandung.

Iswi Hariyani, R.Serfianto, 2010, Bebas Jeratan Utang Piutang, cetakan pertama. Yogyakarta: Pustaka Yustisia.

I Made Pasek Diantha, 2016, Metodologi Penelitian Hukum Normatif dalam Justifikasi Teori Hukum (Jakarta: Prenada Media Grup) .

Munir Fuady, Pengantar Hukum Bisnis, Citra Aditya, Bandung, 2005. 
Mariam Darus Badrulzaman, 2001, AsasAsas Hukum Perjanjian, PT. Citra Aditya Bakti, Bandung,

Nindyo Pramono, 2003, Hukum Komersil, Pusat Penerbitan UT, Jakarta.

Subekti, 2008. Pokok-Pokok Hukum Perdata. PT. Intermasa, Jakarta.

Soerodjo, Irawan.2009, Kepastian Hukum Atas Jaminan Fidusia, Sinar Grafika, Surabaya.

Widjaya, Gunawan dan Ahmad Yani. 2011, Jaminan Fidusia, Raja Grafindo Persada, Bandung.

\section{Peraturan Perundang-undangan :}

Undang-Undang No 1 Tahun 1974 tentang Perkawinan.

Undang-Undang No. 42 Tahun 1999 tentang Jaminan Fidusia.

Peraturan Menteri Keuangan Nomor 130 / PMK.010/2012 tentang Pendaftaran Jaminan Fidusia

\section{Hasil Wawancara}

Wawancara dengan Arista Puspamega, Staff Regional Bussiness Manager Bank Mandiri pada tanggal 4 Juli 2018 . 
BIODATA SINGKAT PENULIS

Fandi Septi Riyanto berprofesi sebagai Advokat/ Konsultan Hukum. Menyelesaikan pendidikan Sarjana Hukum di Fakultas Hukum, Universitas Negeri Jember pada tahun 2016. Pada saat ini tengah menyelesaikan pendidikan Magister pada Program Magister Hukum Fakultas Hukum Universitas Narotama Surabaya. 